ISSN: 1858-4837; E-ISSN: 2598-019X

Volume 16, Nomor 2 (2021),

https://jurnal.uns.ac.id/region

DOI: 10.20961/region.v16i2.47859

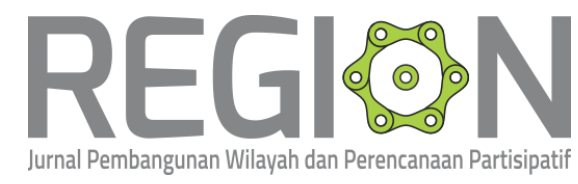

\title{
Eksistensi ruang publik menghadapi transformasi penggunaan ruang di permukiman kota
}

\section{Public space existence facesspace use transformation in urban settlement}

\author{
I R Sushanti ${ }^{1,2}$, S R Yunianti ${ }^{2}$, and T Angelia ${ }^{3}$ \\ ${ }^{1}$ Architecture Department, Faculty of Engineering Planning and Earth, Institut \\ Teknologi Sepuluh Nopember, Surabaya, Indonesia \\ ${ }^{2}$ Urban and Regional Planning Study Program, Faculty of Engineering, Universitas \\ Muhammadiyah Mataram, Mataram, Indonesia \\ ${ }^{3}$ Architecture Study Program, Faculty of Engineering, Universitas Merdeka Surabaya, \\ Surabaya, Indonesia
}

Corresponding author's email: imarahmawati77@gmail.com

\begin{abstract}
Abstrak. Ruang publik hadir memenuhi kebutuhan dan keinginan masyarakat perkotaan melalui interaksi sosial, ekonomi dan budaya. Ruang publik sebagai sarana interaksi bersama warga perkotaan saat ini menghadapi transformasi terkait munculnya pandemi Corona Virus Disease (COVID-19) yang mengancam eksistensi ruang publik. Aturan protokol kesehatan yang wajib dipenuhi setiap individu saat beraktivitas pada akhirnya disarankan pemerintah dan organisasi kesehatan dunia. Setiap individu sebaiknya beraktivitas di rumah tinggal atau lingkungan permukiman sekitarnya untuk mencegah meluasnya pandemi. Hadirnya kebijakan dan pandemi tersebut mempengaruhi individu saat beraktivitas menggunakan ruang publik. Tujuan penelitian adalah mengetahui eksistensi ruang publik di permukiman kota dalam menghadapi transformasi penggunaan ruang yang terjadi. Metode penelitian yang digunakan deskriptif kualitatif berdasarkan studi literatur dan studi kasus pada ruang publik di permukiman kota. Hasil penelitian menunjukkan bahwa eksistensi ruang publik masih terjaga meskipun telah terjadi transformasi penggunaan ruang publik selama pandemi. Upaya adaptasi fisik maupun non fisik diperlukan untuk menghadapi perubahan yang terjadi. Perubahan penggunaan ruang fisik dari skala kota ke skala permukiman kota dihadapi dengan melengkapi fasilitas protokol kesehatan. Perubahan aktivitas penggunaan ruang non fisik dilakukan dengan penerapan kebijakan mematuhi protokol kesehatan bagi warga dan warga wajib
\end{abstract}

Received: January 19, 2021; Accepted: February 26, 2021; Available online: July 15, 2021

Copyright @ 2021, REGION: Jurnal Pembangunan Wilayah dan Perencanaan Partisipatif 
untuk mematuhinya agar terjaga kesehatan dan keselamatannya termasuk memanfaatkan teknologi untuk berinteraksi dan memenuhi kebutuhan hidupnya.

Kata Kunci: Eksistensi; Penggunaan Ruang; Permukiman Kota; Ruang Publik, Transformasi

\begin{abstract}
The present public space fulfills the needs and desires of urban communities through social, economic and cultural interactions. The public space as a means of interaction with urban residents is currently facing a transformation related to the emergence of the Corona Virus Disease (Covid-19) pandemic which threatens the existence of public spaces. Finally, the government and world health organizations recommend the health protocol rules that every individual must comply with while on the move. Each individual should be active in their homes or neighborhoods to prevent the pandemic from spreading. The presence of this policy and the pandemic has affected individuals when using public spaces. The research objective is to determine the existence of public spaces in urban settlements in dealing with the transformation of space use that occurs. The research method used is descriptive qualitative based on literature studies and case studies on public spaces in urban settlements. The results show that the existence of public spaces is still maintained despite the transformation of the use of public spaces during the pandemic. Physical and non-physical adaptation efforts are needed to deal with the changes that occur. Changes in the use of physical space from city scale to urban settlement scale are faced by completing health protocol facilities. Changes in nonphysical space use activities are carried out by implementing policies to comply with health protocols for residents and residents are obliged to comply with it in order to maintain their health and safety, including using technology to interact and meet their daily needs.
\end{abstract}

Keywords: Existence, Public Space, Transformation, Space Use, and Urban Settlements

\title{
1. Pendahuluan
}

Indonesia merupakan negara berkembang, baik dari segi sosial, ekonomi, budaya dan infrastruktur. Oleh karena itu hadirnya fasilitas umum seperti ruang publik diperlukan di setiap daerah. Semakin banyak jumlah ruang publik, maka semakin menguntungkan masyarakat Indonesia. Dalam perkembangannya, ruang publik di Indonesia, selain berfungsi sebagai sarana interaksi sosial, ekonomi dan budaya masyarakat juga sebagai sarana rekreasi atau hiburan yang dapat digunakan sebagai destinasi wisata untuk menarik wisatawan. Namun ruang publik yang ada saat ini masih belum sesuai harapan, baik secara kuantitas dan kualitas. Secara kuantitas keberadaan bangunan berupa gedung atau permukiman di kota masih kurang diimbangi dengan persentase ruang publik yang memadai. Secara kualitas, ruang publik yang sudah ada di beberapa permukiman belum dapat dimanfaatkan oleh masyarakat secara optimal. Hal tersebut disebabkan oleh ruang publik yang ada belum dapat memenuhi fungsinya sebagai ruang publik dengan baik [1]. 
Dalam dinamika yang terjadi saat ini juga telah terjadi perubahan penggunaan ruang oleh individu atau kelompok dalam menggunakan ruang publik. Hal tersebut terjadi karena berlangsungnya pandemi Corona Virus Disease sejak tahun 2019 (Covid-19). Sebagai dampak dari terjadinya pandemi tersebut adalah masyarakat disarankan untuk mematuhi segala protokol kesehatan yang diwajibkan oleh pemerintah dan organisasi kesehatan dunia (World Health Organization/WHO) untuk : 1) menjaga jarak sosial dan fisik (social and physical distancing), 2) mencuci tangan yang bersih serta 3) menggunakan masker. Sebagai respon dari beberapa protokol kesehatan tersebut mengharuskan individu atau kelompok masyarakat untuk dapat mencari alternatif dalam tetap berinteraksi dan berhubungan dengan sesama, komunitas atau institusi dalam rangka tetap memenuhi kebutuhan hidupnya serta keminatan atau harapan yang dimiliki.

Ruang publik sebagai bagian dari ruang harus responsif terhadap kebutuhan pengguna, demokratis dalam aksesibilitasnya, dan berarti bagi komunitas dan masyarakat yang lebih luas [2]. Hal tersebut menunjukkan bahwa ruang publik harus tetap menunjukkan eksistensinya dalam membantu membangun rasa komunitas, identitas dan budaya masyarakat. Tipologi ruang publik secara komprehensif disusun berdasarkan seluruh penggunaan publik pada ruang-ruang kota yang lebih menekankan kepada karakter kegiatan, lokasi dan proses pembentukannya [2]. Tipologi ruang publik dibagi menjadi 11 tipe, yaitu : 1) taman publik, 2) square dan plaza, 3) memorial, 4) pasar, 5) jalan, 6) taman bermain, 7) ruang terbuka komunitas, 8) jalur hijau, 9) perbelanjaan dalam ruang, 10) ruang spontan dalam lingkungan hunian dan 11) tepi air

Ruang publik pada dasarnya memfasilitasi modal sosial, pembangunan ekonomi, dan revitalisasi masyarakat [3]. Eksistensi ruang publik di permukiman sangat penting dalam menjaga kebertahanan permukiman atau kampung yang ditentukan oleh prinsip nilai ruang kebersamaan, kebudayaan dan tradisi [4]. Dan peran ruang publik dapat berubah bergantung cara menggunakannya, baik saat pengguna mengakses dan terlibat dalam domain publik [5].

Ruang publik adalah elemen perkotaan yang memiliki karakter tersendiri dan memiliki fungsi interaksi sosial bagi masyarakat, kegiatan ekonomi dan apresiasi budaya [6]. Menurut sifatnya, ruang publik dibagi dua, yaitu ruang publik tertutup dan ruang publik terbuka [7]. Ruang publik terbuka memiliki pengertian bentuk dasar selalu terletak di luar massa bangunan, dapat dimanfaatkan oleh semua orang dan memberi kesempatan untuk bermacam-macam kegiatan (multifungsi). Secara umum ruang terbuka dibagi menjadi dua jenis, yaitu ruang terbuka privat dan ruang terbuka publik (open spaces) [8]. Sedangkan di perkotaan, ruang terbuka publik terdiri dari ruang terbuka hijau dan ruang terbuka nonhijau.

Ruang publik yang digunakan sebagai tempat aktivitas bersama pada permukiman merupakan suatu proses sosio-spasial yang memadukan antara produksi ruang dan kehidupan masyarakat sehari-hari (the human behaviour setting). Ruang bersama tersebut merupakan tempat aktivitas bagi penghuni permukiman [9]. Ruang publik pada kawasan permukiman di 
Indonesia digunakan secara bersama oleh masyarakat yang tinggal di dalamnya untuk menjalankan aktivitasnya dan mengelola serta mengontrol lingkungannya sehingga sangat perlu dijaga eksistensinya.

Tempat aktivitas publik pada permukiman, terdiri atas: 1) communal place, 2) shared outdoor place dan 3) social space. Communal space merupakan ruang yang menampung kegiatan sosial dan digunakan untuk seluruh masyarakat atau komunitas sehingga memberikan nilai manfaat [10-12]. Shared outdoor place digunakan dan dikelola kelompok masyarakat secara mandiri untuk dapat mengontrol lingkungannya, seperti balai warga, ruang terbuka pada fasilitas publik, dan sebagainya [11]. Sedangkan social space merupakan suatu tempat yang terbentuk karena adanya relasi aktivitas sosial dan budaya dan hubungan anggota masyarakat pada permukiman, seperti gang kampung untuk sarana interaksi warga, mulai sebagai tempat bermain anak-anak dan sarana interaksi antar tetangga $[13,14]$.

Dalam perkembangannya, beberapa perubahan yang terjadi terkait dinamika kebutuhan dan penggunaan ruang yang disebabkan oleh kehadiran teknologi, adanya wabah dan kebijakan [15]. Perubahan yang terjadi telah mengubah struktur sosial-spasial, mengubah budaya jalanan tradisional, mengikis rasa identitas lokal, menciptakan ruang kota yang tidak dapat digunakan dan menimbulkan pertanyaan besar tentang bagaimana ruang tersebut menanggapi kebutuhan dan aspirasi masyarakat [16].

Ada dua proses utama perubahan representasi ruang kota, yaitu perubahan ontogenetik versus filogenetik, atau dalam istilah lain perkembangan spasial dan evolusi spasial [17]. Perubahan representasi ruang kota yang terjadi secara fisik disebut dengan ontogenetik atau terjadi karena perkembangan spasial dan perubahan non fisik disebut dengan filogenetik atau terjadi karena evolusi spasial. Perubahan secara fisik dipengaruhi oleh dinamika perkembangan politik ekonomi dan sosial dan ditunjukkan entitas fisik di ruang kota yang membentuk elemen ranah publik dan privat. Perubahan secara non fisik dipengaruhi kesepakatan manusia atas penggunaan ruang yang berhubungan dengan unsur sosial dalam produksi ruang.

Penggunaan ruang publik telah berubah sepanjang sejarah, yaitu perubahan besar yang dialami kota-kota selama revolusi industri dan teknologi telah mengubah cara orang mengakses dan terlibat dalam domain publik [5]. Tiga alasan yang menyebabkan orang berada di ruang publik, yaitu: kebutuhan kegiatan (necessary activities), kegiatan opsional (optional activities) dan kegiatan sosial (social activities) yang dihasilkan [5].

Penggunaan ruang publik di perkotaan saat ini semakin berkembang. Ruang publik tidak hanya dijadikan sebagai sarana interaksi bersama individu tetapi juga komunitas untuk bertemu, berkumpul dan berkreasi untuk meningkatkan kualitas hidup secara ekonomi. Karakteristik ruang publik di permukiman kota secara fisik merupakan ruang bersama yang digunakan masyarakat untuk berinteraksi secara sosial dan ekonomi $[18,19]$ sehingga mencerminkan perilaku pengguna terhadap tempat. 
Dalam perkembangan revolusi industri 4.0, individu atau kelompok masyarakat pada akhirnya menggunakan alternatif teknologi atau jejaring melalui media sosial untuk tetap terus berhubungan dan berinteraksi satu dengan yang lainnya. Penggunaan ruang publik oleh individu atau kelompok masyarakat secara fisik seminimal mungkin pada akhirnya membuka akses penggunaan ruang publik secara non fisik untuk digunakan dalam proses interaksinya. Perubahan penggunan ruang publik secara non fisik melalui aktivitas sosial, ekonomi dan budaya melalui teknologi mempengaruhi eksistensi penggunaan ruang publik secara fisik.

Penelitian ini berupaya untuk mengidentifikasi kembali fungsi ruang publik terkait perubahan penggunaan ruang yang terjadi, baik secara fisik dan nonfisik khususnya dalam merespon terjadinya pandemi Covid-19. Hal tersebut dilakukan dalam rangka menjaga eksistensi ruang publik secara berkelanjutan dengan melibatkan seluruh individu dan komunitas terkait aktivitas penggunaan ruang yang terjadi di dalamnya sehingga mampu menghadapi dinamika perubahan penggunaan ruang yang terjadi bahkan upaya untuk menata kembali ruang publik secara fisik sebagai akibat dari perubahan aktivitas penggunaan ruang.

\section{Metode}

Metode penelitian yang digunakan dalam studi ini adalah metode kombinasi, yaitu deskriptif kualitatif dan studi kasus [20]. Penelitian kualitatif merupakan suatu prosedur penelitian yang menghasilkan data deskriptif berupa ucapan atau tulisan dan perilaku yang dapat diamati dari orang-orang (subyek) itu sendiri. Dalam penelitian ini dilakukan kajian literatur, kebijakan dan studi kasus yang menggambarkan potensi dan masalah yang terjadi untuk dapat mengidentifikasi dan mengkaji eksistensi ruang publik di permukiman kota. Jenis data yang diambil dalam penelitian ini adalah data primer dan data sekunder. Data didapatkan berdasarkan pengumpulan data primer melalui pengamatan dan wawancara pada wilayah studi kasus. Penentuan partisipan dilakukan dengan menggunakan purposive sampling dengan penelusuran dan wawancara yang mendalam. Penentuan sampel partisipan dengan menetapkan ciri khusus sesuai tujuan penelitian. Setiap anggota populasi mempunyai kesempatan yang sama untuk dijadikan sampel [20]. Partisipan terdiri atas warga yang tinggal di Kelurahan Pagutan Barat, Kecamatan Mataram di Kota Mataram dengan kriteria yang menggunakan ruang publik. Partisipan aparat pemerintah dan swasta dengan jumlah total 20 orang. Partisipan warga dengan kriteria yang menggunakan ruang publik sejumlah 15 orang mewakili kelompok anak-anak (usia $12-17$ tahun), kelompok remaja (usia 17 -25 tahun), kelompok dewasa (26 - 65 tahun), kelompok lanjut usia (>65 tahun ke atas) dan kelompok penjual di pasar kelurahan/lapangan serbaguna. Partisipan aparat pemerintah/kelurahan dan swasta sejumlah 5 orang dengan kriteria yang mengetahui kebijakan terkait penggunaan ruang publik. Data sekunder diperoleh melalui studi literatur berupa artikel, buku, tesis atau disertasi serta kebijakan. Ruang lingkup penelitian ini adalah ruang publik di permukiman Kelurahan Pagutan Barat, Kecamatan Mataram di Kota Mataram. Dalam hal ini kondisi ruang publik disajikan secara deskriptif baik dalam aspek kuantitas dan kualitas ruang publik, khususnya yang terjadi saat 
sebelum dan sesudah pandemi Covid-19 terjadi tekait penggunaan ruang oleh individu atau kelompok masyarakat. Waktu penelitian dilakukan selama kurang lebih tiga bulan saat pandemi sedang terjadi, yaitu dalam rentang waktu bulan Juni sampai dengan Agustus tahun 2020.

Teknik analisis yang digunakan adalah analisis komparasi penggunaan ruang publik sebelum dan saat terjadi pandemi Covid-19 sehingga dapat diperoleh hasil terkait transformasi atau perubahan penggunaan ruang yang terjadi saat sebelum dan saat pandemi berlangsung.

Komparasi dilakukan dengan memperhatikan fungsi ruang publik dan jenis aktivitas yang berlangsung di dalamnya saat sebelum dan saat pandemi terjadi berdasarkan data dokumentasi dan hasil wawancara dengan partisipan. Selanjutnya dilakukan kajian dan simpulan tentang transformasi ruang publik terhadap eksistensi ruang publik dalam kaitannya dengan fungsi ruang. Variabel penelitian ini berhubungan dengan eksistensi ruang publik yang meliputi aspek-aspek fungsi ruang publik, yaitu : 1) responsif, 2) demokratis dan 3) bermakna. Responsif artinya ruang publik harus tanggap akan kebutuhan-kebutuhan para pengguna lewat fasilitas, desain fisik dan pengelolaannya. Demokratis artinya pengguna memiliki kemudahan aksesibilitas, visual dan ruang publik dapat menjamin kebebasan beraktivitas pengguna. Bermakna artinya ada sistem pemaknaan dalam ruang publik, yaitu memungkinkan pengguna untuk membuat hubungan dengan ruang sehubungan dengan peristiwa lain, mendukung aktivitas para pengguna ruang, membuat rasa nyaman dan aman.

\section{Hasil dan pembahasan}

Dinamika perkembangan penggunaan ruang publik di perkotaan, baik di kota-kota besar maupun di permukiman kota pada saat ini terjadi seiring dengan munculnya pandemi Covid19 yang pada akhirnya menuntut ruang publik dan pengguna memberikan respon dengan seting dan peran yang berbeda dan bahkan mengarah ke perubahan.

Perubahan penggunaan ruang publik pada saat ini tidak dipungkiri terjadi dalam aspek fisik maupun non fisik. Secara fisik ruang publik di kota-kota besar di Indonesia khususnya, mencoba untuk merepresentasikan kebijakan atau peraturan terkait yang mensyaratkan keberadaan ruang terbuka hijau publik memenuhi persyaratan $20 \%$. Beberapa kota besar di Indonesia ada yang berhasil menerapkan kebijakan tersebut sebagai entitas fisik dari ruang publik, ada yang telah memenuhinya, yaitu Kota Surabaya, bahkan telah mencapai $21,79 \%$ [21] tetapi beberapa kota yang lain belum bisa memenuhinya dengan beberapa kendala, khususnya terkait komitmen dan konsistensi seluruh unsur stakeholders di dalamnya terhadap kebijakan yang telah diambil.

\subsection{Penggunaan ruang publik saat pandemi Covid-19}

Munculnya pandemi Covid-19 pada tahun 2019 pada akhirnya membawa perubahan terhadap penggunaan ruang publik secara fisik dan non fisik. Kebijakan pemerintah dan WHO untuk mengurangi dampak meluasnya pandemi dengan bekerja dari rumah (work from home) atau melakukan aktivitas dari rumah lebih disarankan. Beberapa kota besar seperti Jakarta, Surabaya, Bandung dan Bogor bahkan juga menerapkan Pembatasan Sosial Berskala 
Besar (PSBB) karena meningkatnya jumlah penderita Covid-19 sehingga meluas di beberapa titik lokasi dan wilayah tersebut berubah menjadi zona merah. Apabila masyarakat bepergian ke ruang atau fasilitas publik maka kebijakan protokoler kesehatan untuk menghindari terpaparnya Covid-19 juga harus diperhatikan dan dijalankan, seperti : 1) menjaga jarak, 2) menggunakan masker dan 3) mencuci tangan.

Dari beberapa kondisi yang terjadi memberikan pengaruh pada aktivitas masyarakat pada saat pandemi terjadi, di antaranya: 1) Masyarakat mengurangi aktivitas bepergian atau keluar rumah, 2) Masyarakat memanfaatkan teknologi untuk bekerja, belajar, berinteraksi atau berbelanja dalam rangka memenuhi kebutuhan dari rumah, 3) Masyarakat mematuhi protokol kesehatan saat berada di ruang publik. Berdasarkan hal-hal tersebut maka dapat diketahui bahwa keberadaan ruang publik di perkotaan secara fungsi menjadi minim karena aktivitas masyarakat lebih terkonsentrasi di unit rumah tinggal atau lingkungan yang terdekat, yaitu ruang publik di permukiman kota. Hal tersebut menunjukkan bahwa secara fisik telah terjadi perkembangan spasial dimana penggunaan ruang publik oleh masyarakat untuk beraktivitas berubah dari ranah publik di perkotaan (urban) ke ranah publik dalam skala lingkungan permukiman (neighborhood). Perubahan penggunaan ruang secara non fisik sebagai dampak dari munculnya pandemi, hadirnya teknologi dan kebijakan menunjukkan bahwa masyarakat tetap terus berupaya untuk bertahan dalam menjalani kehidupan dan memenuhi kebutuhannya dengan melakukan beberapa adaptasi secara inklusif dengan tetap mematuhi protokol kesehatan saat menggunakan ruang publik, baik di perkotaan maupun di permukiman kota.

\subsection{Ruang publik di permukiman kota}

Ruang publik di permukiman kota merupakan ruang-ruang publik terbuka yang pada saat sebelum pandemi Covid-19 dapat digunakan warga permukiman untuk menjalankan aktivitas bersama dalam wujud interaksi sosial. Identifikasi terkait penggunaan ruang publik di permukiman kota dilakukan untuk mengetahui dinamika perkembangan ruang selama pandemi Covid-19 berlangsung setelah terjadi perubahan fisik maupun non fisik dari penggunaan ruang spasial skala perkotaan ke skala permukiman.

Ruang publik di permukiman kota yang diambil sebagai studi kasus ini berada di wilayah Kelurahan Pagutan Barat, Kecamatan Mataram, Kota Mataram yang merupakan salah satu kawasan dengan fungsi peruntukkan sebagai kawasan permukiman kota yang memiliki keragaman tipologi ruang publik. Kelurahan Pagutan Barat memiliki luas wilayah sebesar 0,91 km² dengan jumlah penduduk 12.719 jiwa dan tingkat kepadatan $13.977 \mathrm{jiwa} / \mathrm{km}^{2}$ yang termasuk dalam tingkat kepadatan penduduk sedang dan memiliki sebaran kepadatan bangunan mencapai hampir $70 \%$ luas wilayah [22]. Kawasan permukiman yang ada di Kelurahan Pagutan Barat terdiri dari perumahan milik pemerintah, swasta dan perseorangan serta beberapa fasilitas umum yang mendukung, yaitu: 1) fasilitas pendidikan berupa Taman Kanak-Kanak, SD, SMP, dan SMK; 2) fasilitas peribadatan berupa masjid dan pura; 3) fasilitas ekonomi, yaitu pasar dan koperasi; 4) fasilitas kesehatan berupa posyandu; dan 5) ruang publik serta 6) prasarana lainnya. 
Persebaran ruang publik yang digunakan warga di Kelurahan Pagutan Barat dapat dilihat dalam peta persebaran ruang publik pada Gambar 1 berikut.

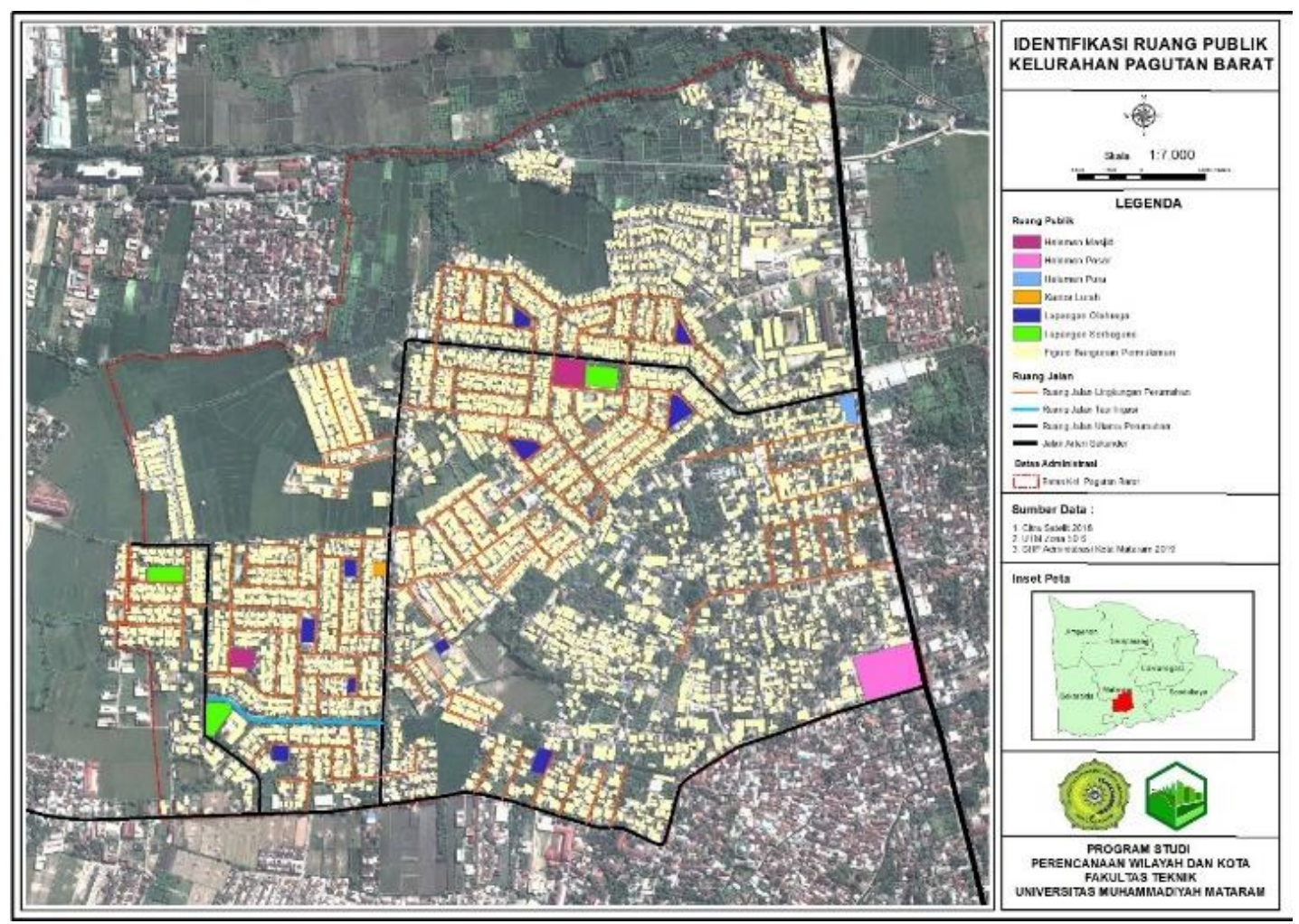

Gambar 1. Peta persebaran ruang publik di kawasan permukiman Pagutan Barat.

Ruang publik yang digunakan warga di Kelurahan Pagutan Barat dalam melakukan aktivitas bersama atau interaksi sosial dapat diklasifikasikan dan dilihat pada Tabel 1 berikut.

Tabel 1. Klasifikasi ruang publik di permukiman kota, Kelurahan Pagutan Barat, Kecamatan Mataram, Kota Mataram.

\begin{tabular}{|c|c|c|c|}
\hline No & $\begin{array}{l}\text { Tipologi/Jenis } \\
\text { Ruang Publik }\end{array}$ & Fungsi & Dokumentasi \\
\hline 1 & $\begin{array}{lr}\text { Ruang } & \text { komunal/ } \\
\text { Ruang } & \text { jalan } \\
\text { utama } & \end{array}$ & $\begin{array}{l}\text { Akses utama warga masuk atau } \\
\text { keluar permukiman dan } \\
\text { berbatasan langsung dengan } \\
\text { hunian warga. }\end{array}$ & \\
\hline 2 & $\begin{array}{lr}\text { Ruang } & \text { sosial/ } \\
\text { Ruang } & \text { jalan } \\
\text { lingkungan } & \end{array}$ & $\begin{array}{l}\text { Akses penghubung rumah warga } \\
\text { dengan ruang jalan utama dan } \\
\text { berbatasan langsung dengan } \\
\text { hunian warga }\end{array}$ & \\
\hline
\end{tabular}




\begin{tabular}{clll}
\hline No & $\begin{array}{l}\text { Tipologi/Jenis } \\
\text { Ruang Publik }\end{array}$ & \multicolumn{1}{c}{ Fungsi } \\
\hline 3 & $\begin{array}{l}\text { Ruang sosial / Jalan atau jalur penghubung } \\
\text { Ruang jalan tepi } \\
\text { irigasi }\end{array}$ & $\begin{array}{l}\text { rumah warga dengan ruang jalan } \\
\text { utama atau jalan lingkungan yang } \\
\text { berada di dua sisi sungai yang } \\
\text { membelah di tengahnya }\end{array}$ \\
\hline 4 & $\begin{array}{l}\text { Ruang komunal } \\
\text { /Lapangan } \\
\text { serbaguna }\end{array}$ & $\begin{array}{l}\text { Ruang publik yang digunakan } \\
\text { warga untuk beraktivitas bersama, } \\
\text { baik yang mendukung aktivitas } \\
\text { sosial, ekonomi atau budaya }\end{array}$ \\
& &
\end{tabular}

5 Ruang berbagi/ Ruang publik yang digunakan Lapangan warga untuk beraktivitas olahraga, olahraga seperti bulu tangkis, basket, volly, jogging, atau sepak bola, sekaligus parkir kendaraan

\begin{tabular}{|c|c|c|}
\hline 6 & $\begin{array}{l}\text { Ruang berbagi/ } \\
\text { Halaman kantor } \\
\text { kelurahan }\end{array}$ & $\begin{array}{l}\text { Ruang publik yang digunakan } \\
\text { warga untuk mendukung kegiatan } \\
\text { yang berhubungan dengan }\end{array}$ \\
\hline & & $\begin{array}{l}\text { kelengkapan administrasi, } \\
\text { kependudukan atau aktivitas } \\
\text { publik lainnya. }\end{array}$ \\
\hline 7 & $\begin{array}{l}\text { Ruang komunal/ } \\
\text { Halaman pasar } \\
\text { kelurahan }\end{array}$ & $\begin{array}{l}\text { Ruang publik yang digunakan } \\
\text { warga untuk mendukung kegiatan } \\
\text { yang berhubungan dengan } \\
\text { kegiatan perekonomian dan } \\
\text { perdagangan, bahkan juga } \\
\text { aktivitas publik lainnya, seperti } \\
\text { bermain atau berolah raga bagi } \\
\text { anak-anak di sekitarnya. }\end{array}$ \\
\hline
\end{tabular}
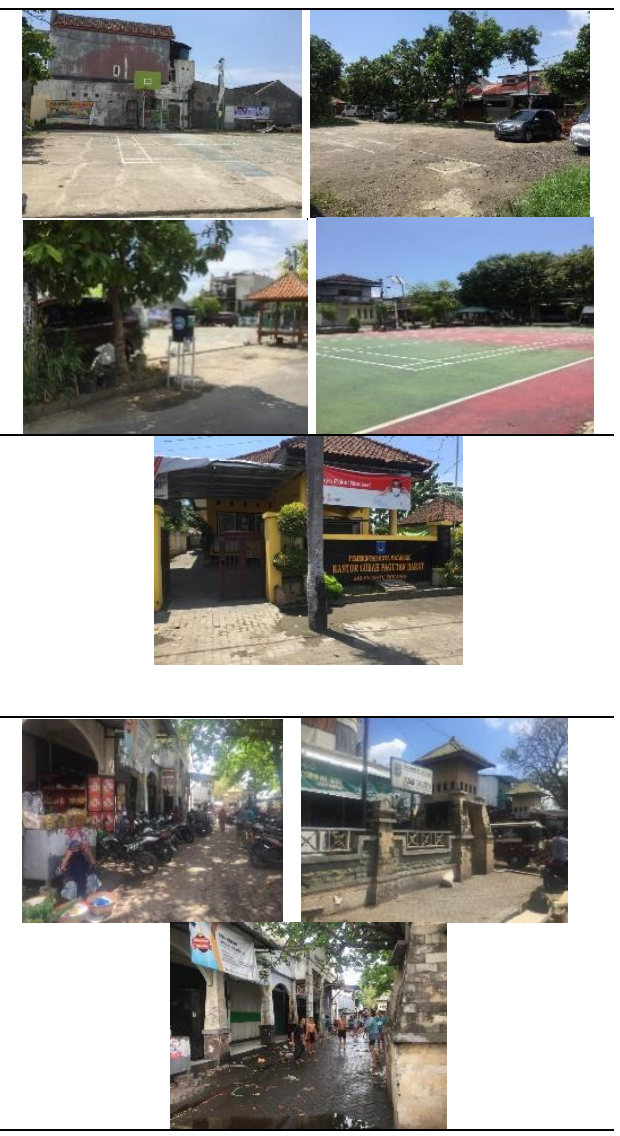

8 Ruang berbagi/ Ruang publik yang digunakan Halaman masjid warga untuk mendukung kegiatan yang berhubungan dengan kegiatan keagamaan bagi warga yang beragama Islam juga aktivitas publik lainnya, seperti parkir.

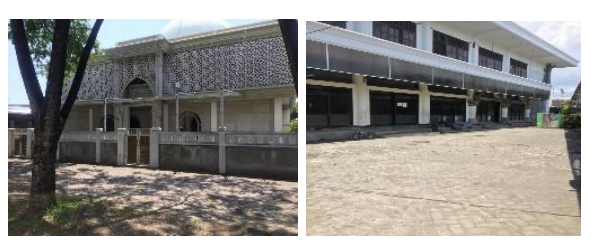




\begin{tabular}{cll}
\hline No & $\begin{array}{l}\text { Tipologi/Jenis } \\
\text { Ruang Publik }\end{array}$ & \multicolumn{1}{c}{ Fungsi } \\
\hline 9 & Ruang berbagi/ & Ruang publik yang digunakan \\
& Halaman pura & warga untuk mendukung kegiatan \\
& yang berhubungan dengan \\
& kegiatan keagamaan bagi warga \\
& yang beragama Hindu juga \\
& aktivitas publik lainnya, seperti \\
& parkir
\end{tabular}

\subsection{Fungsi ruang publik}

Fungsi ruang publik di kawasan permukiman yang berada di Kelurahan Pagutan Barat, Kecamatan Mataram, Kota Mataram mengalami perubahan karena berlangsungnya pandemi Covid-19. Perubahan penggunaan ruang yang terjadi, khususnya pada aktivitas bercengkerama atau mengobrol sebagai bentuk interaksi sosial yang biasanya secara langsung dilakukan di ruang publik menjadi minim bahkan dihindari untuk mencegah meluasnya pandemi. Warga lebih banyak menggunakan teknologi melalui jejaring sosial untuk tetap menjaga interaksi sosial dan berbagi informasi. Akan tetapi, hal tersebut tidak mengurangi eksistensi ruang publik terhadap peggunaan ruang oleh aktivitas warga, khususnya yang bernilai ekonomi atau keagamaan dengan tetap menerapkan protokol kesehatan. Hal tersebut dapat dilihat dari aktivitas yang berbeda dalam penggunaan ruang publik oleh warga, sebagaimana dapat dilihat pada Tabel 3.

Tabel 3. Transformasi ruang publik di permukiman kota berdasarkan aktivitas warga Kelurahan Pagutan Barat, Kecamatan Mataram, Kota Mataram

\begin{tabular}{|c|c|c|c|c|}
\hline \multirow[b]{2}{*}{ No } & \multirow[b]{2}{*}{ Ruang Publik } & \multirow[b]{2}{*}{$\begin{array}{l}\text { Kategori } \\
\text { Aktivitas }\end{array}$} & \multicolumn{2}{|c|}{ Jenis Aktivitas } \\
\hline & & & $\begin{array}{c}\text { Aktivitas } \\
\text { Sebelum Pandemi }\end{array}$ & $\begin{array}{c}\text { Aktivitas } \\
\text { Saat Pandemi }\end{array}$ \\
\hline \multirow[t]{3}{*}{1} & Ruang jalan & Aktivitas & $>$ Berjualan & $>$ Berjualan \\
\hline & utama & $\begin{array}{l}\text { Komersiil/ } \\
\text { Ekonomi }\end{array}$ & $>$ Berbelanja & $\begin{array}{l}\text { B Berbelanja } \\
\text { - Protokol Kesehatan }\end{array}$ \\
\hline & & Aktivitas Servis & Parkir & Parkir \\
\hline \multirow[t]{2}{*}{2} & $\begin{array}{l}\text { Ruang jalan } \\
\text { lingkungan }\end{array}$ & Sosial Rutin & $\begin{array}{l}>\text { Ngobrol } \\
>\text { Bermain }\end{array}$ & Bermain \\
\hline & & Aktivitas Servis & Parkir & Parkir \\
\hline \multirow[t]{2}{*}{3} & $\begin{array}{l}\text { Ruang jalan } \\
\text { tepi sungai }\end{array}$ & Sosial Rutin & $\begin{array}{l}>\text { Ngobrol } \\
>\text { Bermain } \\
>\text { Memancing }\end{array}$ & $\begin{array}{l}>\text { Bermain } \\
>\text { Memancing }\end{array}$ \\
\hline & & Aktivitas Servis & Parkir & Parkir \\
\hline 4 & $\begin{array}{l}\text { Lapangan } \\
\text { serbaguna }\end{array}$ & $\begin{array}{l}\text { Sosial } \\
\text { Temporal }\end{array}$ & $\begin{array}{l}\text { D Olahraga } \\
>\text { Bazar Murah } \\
\text { Bazar Ramadhan } \\
\text { Kegiatan keagamaan; sholat } \\
\text { led, pengajian akbar, } \\
\text { pembagian zakat, }\end{array}$ & $\begin{array}{l}\text { Dazar Murah } \\
\text { Bazar Ramadhan } \\
\text { - Protokol Kesehatan }\end{array}$ \\
\hline
\end{tabular}

Received: January 19, 2021; Accepted: February 26, 2021; Available online: July 15, 2021

Copyright @ 2021, REGION: Jurnal Pembangunan Wilayah dan Perencanaan Partisipatif 


\begin{tabular}{|c|c|c|c|c|}
\hline \multirow[b]{2}{*}{ No } & \multirow[b]{2}{*}{ Ruang Publik } & \multirow{2}{*}{$\begin{array}{l}\text { Kategori } \\
\text { Aktivitas }\end{array}$} & \multicolumn{2}{|c|}{ Jenis Aktivitas } \\
\hline & & & \multirow{2}{*}{\begin{tabular}{l} 
Aktivitas \\
\multicolumn{1}{c}{ Sebelum Pandemi } \\
pemotongan hewan kurban \\
dan pembagian hewan \\
kurban \\
Kegiatan peringatan hari \\
kemerdakaan: panggung \\
hiburan dan lomba-lomba \\
\end{tabular}} & \multirow[t]{2}{*}{$\begin{array}{c}\text { Aktivitas } \\
\text { Saat Pandemi }\end{array}$} \\
\hline & & & & \\
\hline & & Sosial Rutin & $\begin{array}{l}>\text { Ngobrol } \\
>\text { Bermain }\end{array}$ & Bermain \\
\hline & & $\begin{array}{l}\text { Aktivitas } \\
\text { Komersiil/ } \\
\text { Ekonomi }\end{array}$ & $\begin{array}{l}>\text { Berjualan } \\
>\text { Berbelanja }\end{array}$ & $\begin{array}{l}\text { Berjualan } \\
>\text { Berbelanja } \\
\text { - Protokol Kesehatan }\end{array}$ \\
\hline & & Aktivitas Servis & Parkir & Parkir \\
\hline \multirow[t]{3}{*}{5} & $\begin{array}{l}\text { Lapangan } \\
\text { olahraga }\end{array}$ & $\begin{array}{l}\text { Sosial } \\
\text { Temporal }\end{array}$ & Olahraga & $\begin{array}{l}\text { Olahraga } \\
\text { - Protokol Kesehatan }\end{array}$ \\
\hline & & Sosial Rutin & $\begin{array}{l}>\text { Ngobrol } \\
>\text { Bermain }\end{array}$ & $\begin{array}{l}\text { Bermain } \\
\text { - Protokol Kesehatan }\end{array}$ \\
\hline & & Aktivitas Servis & Parkir & Parkir \\
\hline \multirow[t]{2}{*}{6} & $\begin{array}{l}\text { Halaman } \\
\text { kantor }\end{array}$ & Sosial Rutin & Ngobrol & $\begin{array}{l}\text { Ngobrol } \\
\text { - Protokol Kesehatan }\end{array}$ \\
\hline & kelurahan & Aktivitas Servis & Parkir & Parkir \\
\hline \multirow[t]{3}{*}{7} & $\begin{array}{l}\text { Halaman pasar } \\
\text { kelurahan }\end{array}$ & $\begin{array}{l}\text { Aktivitas } \\
\text { Komersiil/ } \\
\text { Ekonomi }\end{array}$ & $\begin{array}{l}>\text { Berjualan } \\
>\text { Berbelanja }\end{array}$ & $\begin{array}{l}\text { D Berjualan } \\
\text { Berbelanja } \\
\text { - Protokol Kesehatan }\end{array}$ \\
\hline & & Sosial Rutin & $\begin{array}{l}>\text { Ngobrol } \\
>\text { Bermain }\end{array}$ & Bermain \\
\hline & & Aktivitas Servis & Parkir & Parkir \\
\hline \multirow[t]{4}{*}{8} & $\begin{array}{l}\text { Halaman } \\
\text { masjid }\end{array}$ & Sosial Rutin & $\begin{array}{l}\text { > Sholat Jamaah Lima Waktu } \\
\text { > Sholat Jamaah Jum'at } \\
>\text { Mengaji } \\
>\text { Kajian Islami }\end{array}$ & $\begin{array}{l}\text { D Sholat Jamaah Lima } \\
\text { Waktu } \\
\text { S Sholat Jamaah Jum'at } \\
>\text { Mengaji } \\
\text { - Kajian Islami } \\
\text { - Protokol Kesehatan }\end{array}$ \\
\hline & & $\begin{array}{l}\text { Sosial } \\
\text { Temporal }\end{array}$ & $\begin{array}{l}\text { Pengajian bulanan } \\
>\text { Pengajian akbar }\end{array}$ & $\begin{array}{l}>\text { Pengajian bulanan } \\
>\text { Pengajian akbar }\end{array}$ \\
\hline & & & $\begin{array}{c}\text { Peringatan Hari Besar } \\
\text { Keagamaan }\end{array}$ & $\begin{array}{l}\text { Peringatan Hari } \\
\text { Besar Keagamaan } \\
\text { - Protokol Kesehatan }\end{array}$ \\
\hline & & Aktivitas Servis & Parkir & Parkir \\
\hline 9 & Halaman pura & Sosial Rutin & Persembahyangan & \begin{tabular}{l}
\multicolumn{2}{l}{ Persembahyangan } \\
dengan pembatasan \\
(perwakilan anggota \\
keluarga/20 orang \\
setiap kali sembahyang)
\end{tabular} \\
\hline
\end{tabular}




\begin{tabular}{|c|c|c|c|c|c|c|c|}
\hline \multirow[b]{2}{*}{ No } & \multirow[b]{2}{*}{ Ruang Publik } & \multirow{2}{*}{$\begin{array}{l}\text { Kategori } \\
\text { Aktivitas }\end{array}$} & \multicolumn{5}{|c|}{ Jenis Aktivitas } \\
\hline & & & \multicolumn{3}{|c|}{$\begin{array}{c}\text { Aktivitas } \\
\text { Sebelum Pandemi }\end{array}$} & \multicolumn{2}{|c|}{$\begin{array}{c}\text { Aktivitas } \\
\text { Saat Pandemi }\end{array}$} \\
\hline & & & & & & \multicolumn{2}{|c|}{ - Protokol Kesehatan } \\
\hline & & \multirow{5}{*}{$\begin{array}{l}\text { Sosial } \\
\text { Temporal }\end{array}$} & \multirow{2}{*}{$\begin{array}{l}\text { Ritual } \\
\text { Manusayadny } \\
\text { (pernikahan, } \\
\text { dan lain-lain) }\end{array}$} & \multicolumn{2}{|c|}{ upacara } & \multicolumn{2}{|c|}{$>$ Ritual upacara } \\
\hline & & & & ya & baligh, & \multicolumn{2}{|c|}{$\begin{array}{l}\text { Manusayadnya } \\
\text { (pernikahan, akil } \\
\text { baligh, dan lain-lain) }\end{array}$} \\
\hline & & & $\begin{array}{l}\text { Pertunjukan } \\
\text { budaya }\end{array}$ & seni & dan & $\begin{array}{l}>\text { Pertunjukan } \\
\text { dan budaya }\end{array}$ & seni \\
\hline & & & $>$ Peringatan & Habi & Besar & $>$ Peringatan & Habi \\
\hline & & & \multicolumn{3}{|c|}{ Keagamaan } & \multicolumn{2}{|c|}{ Besar Keagamaan } \\
\hline & & Aktivitas Servis & \multicolumn{3}{|l|}{ Parkir } & \multicolumn{2}{|l|}{ Parkir } \\
\hline
\end{tabular}

\subsection{Transformasi penggunaan ruang}

Berdasarkan hasil identifikasi dan analisis terkait penggunaan ruang publik di permukiman maka dapat diketahui bahwa beberapa fungsi ruang publik yang terdapat di wilayah Kelurahan Pagutan Barat mengalami transformasi dalam hal terjadinya perubahan aktivitas penggunaan ruang publik saat pandemi Covid-19 tetapi tidak mengurangi, merubah atau menghilangkan fungsi ruang publik. Perubahan aktivitas penggunaan ruang terjadi pada ruang publik yang mewadahi aktivitas sosial temporal dan rutin. Pada aktivitas sosial dan temporal mengalami pengurangan aktivitas, khususnya sebagai sarana interaksi sosial warga untuk mengobrol atau aktivitas yang memicu keramaian atau kerumunan, seperti peringatan hari besar atau libur nasional.

Beberapa ruang publik di permukiman tersebut telah menyediakan protokol kesehatan tetapi ada juga yang masih belum menyediakan. Masyarakat sendiri sebagian besar saat beraktivitas menggunakan ruang publik telah mengikuti protokol kesehatan tetapi masih belum dilakukan pengaturan jarak pada ruang publik yang digunakan masyarakat untuk aktivitas ekonomi, baik untuk penjual maupun pembeli sehingga bahaya Covid-19 tentunya masih beresiko terjadi.

\subsection{Eksistensi ruang publik di permukiman kota}

Terjadinya transformasi atau perubahan penggunaan ruang berdasarkan perubahan aktivitas penggunaan ruang publik saat pandemi Covid-19 tidak mengurangi, merubah atau menghilangkan fungsi ruang public sehingga menunjukkan bahwa eksistensi ruang publik masih terjaga. Hal tersebut menjadi temuan dari penelitian terkait penggunaan ruang publik saat masa pandemi. Dalam rangka menjaga eksistensi ruang publik secara berkelanjutan saat atau sesudah menghadapi pandemi tentunya diperlukan upaya pengendalian terhadap aspek fisik ruang publik yang menyangkut fasilitas dan penataan kondisi lingkungan ruang publik serta aspek non fisik yang menyangkut pengguna saat beraktivitas dalam menggunakan ruang publik. Upaya adaptasi secara fisik maupun non fisik untuk menjaga dan 
mengendalikan eksistensi ruang publik agar tetap terjaga kualitasnya dan berfungsi secara optimal sebagai sarana interaksi sosial, budaya dan ekonomi menjadi kebaharuan dari penelitian tentang penggunaan ruang publik saat pandemi berlangsung yang dapat ditingkatkan secara nilai dan manfaat untuk penggunaan ruang publik sesudah pandemi berlangsung atau di masa yang akan datang.

Hal tersebut tentunya berbeda dan menjadi strategi atau kontribusi penelitian yang lebih bernilai dalam melengkapi dari penelitian terkait fungsi ruang publik di permukiman padat perkotaan yang lebih mengidentifikasi aktivitas dan merespon aspek sosial dan lingkungan tanpa upaya adaptasi, baik secara fisik (lingkungan) dan non fisik (sosial) yang harus dilakukan [23].

Upaya adaptasi penggunaan ruang dilakukan dengan memperhatikan fungsi ruang publik sehingga tetap dapat menjalankan eksistensinya dengan optimal, yaitu:

1) Responsif terhadap kebutuhan pengguna, yang ditunjukkan dengan kemampuan ruang publik dapat mengakomodir kebutuhan sosial dan ekonomi pengguna atau warga dengan tetap menjaga keamanan dan kenyamanan pengguna atau warga yang terlibat di dalamnya

2) Demokratis dalam aksesibilitasnya, yaitu pengguna atau warga permukiman dapat menggunakan ruang publik dengan tetap tersedianya fasilitas yang berhubungan dengan protokol kesehatan.

3) Berarti bagi komunitas dan masyarakat, bahwa warga tetap dapat menjalankan aktivitas yang dapat memberikan nilai manfaat, baik sosial, ekonomi, dan budaya secara proporsional.

\section{Kesimpulan}

Transformasi penggunaan ruang publik ditunjukkan dengan terjadinya perubahan penggunaan ruang sebagai akibat terjadinya pandemi Covid-19 memberikan pengaruh secara fisik maupun non fisik terhadap eksistensi ruang publik. Ruang publik di perkotaan yang biasanya digunakan warga kota menjadi berkurang eksistensinya. Penggunaan ruang publik yang biasanya didominasi oleh ruang publik perkotaan menjadi bergeser ke ranah penggunaan ruang publik pada skala permukiman kota. Kebijakan pemerintah dan WHO agar masyarakat lebih baik beraktivitas dari rumah atau di lingkungan terdekatnya dengan menggunakan teknologi atau melalui jejaring sosial juga memberikan pengaruh terhadap masyarakat untuk melakukan adaptasi atau menyesuaikan diri agar tetap dapat mempertahankan kelangsungan hidupnya.

Upaya-upaya yang melibatkan pemerintah, masyarakat dan stakeholders dilakukan dengan bersinergi dalam melakukan restorasi ruang publik, khususnya di permukiman kota, baik secara fisik maupun non fisik sehingga eksistensi ruang publik dapat terjaga, terpelihara dan berkelanjutan. Hal tersebut dapat dilakukan dengan upaya sebagai berikut.

1) Penataan kembali ruang publik dengan konsep adaptif dan inklusif, yaitu memperhatikan jarak sosial dan fisik bagi pengguna atau fasilitas yang disediakan secara terpadu dengan melibatkan warga permukiman atau masyarakat perkotaan 
2) Menyediakan fasilitas yang aman dan nyaman dengan protokol kesehatan di seluruh titik ruang publik dan menjaga kebersihan ruang publik.

3) Mengatur penyelenggarakan kegiatan bersama dan pembatasan pengguna ruang publik secara proporsional.

4) Memberikan edukasi dan sosialisasi yang interaktif dan terpadu bagi warga permukiman atau masyarakat perkotaan saat menggunakan ruang publik.

5) Menyediakan fasilitas ruang publik yang dapat memberikan nilai manfaat bagi pengguna secara efisien dan efektif.

6) Memanfaatkan teknologi untuk dapat mengidentifikasi pengguna yang mengakses ruang publik dan memberikan informasi terkait kegiatan publik yang akan berlangsung.

Dalam perkembangan penelitian lanjutan terkait eksistensi ruang publik dapat dilakukan dengan menentukan konsep dan perencanaan ruang publik yang berhubungan dengan fungsi ruang publik sehingga mampu merespon terjadinya pandemi yang saat ini sedang terjadi. Pertimbangan hadirnya pandemi sebagai bencana non alam dalam konsep dan perencanaan ruang publik dengan beberapa protokol kesehatan yang harus dipatuhi oleh individu atau komunitas dalam menggunakan ruang publik menjadi aspek-aspek yang menjadi perhatian. Hal tersebut dilakukan dalam rangka menjaga kesehatan dan keberlangsungan hidup dari pengguna serta keberlanjutan ruang publik. Peran teknologi sebagai infrastruktur yang saat ini berperan penting untuk menjaga eksistensi ruang publik sebagai sarana adaptasi individu atau komunitas dalam menghadapi pandemi tentunya juga melibatkan partisipasi beberapa pihak atau stakeholders sehingga ruang publik dapat terjaga keberlanjutannya.

\section{Referensi}

[1] Ching FDK. Arsitektur : Bentuk Ruang dan Tatanan. Jakarta: Erlangga; 1993.

[2] Carr S, Francis M, Rivlin LG, Stone AM. Public Space. Australia: Press Syndicate of University of Cambridge; 1992.

[3] Andersson C. Public Space and the New Urban Agenda. J Public Sp 2016;1:5-10. https://doi.org/10.5204/jps.v1i1.4.

[4] Juwono S. Kampung Kuningan di Kawasan Mega Kuningan Jakarta. Universitas Diponegoro, 2009.

[5] Gehl J. Cities for People. Washington: Island Press; 2010.

[6] Darmawan E. Peranan Ruang Publik Dalam Perancangan Kota (Urban Design). Pidato Pengukuhan Guru Besar Dalam Ilmu Arsitektur, Fak. Tek. Univ. Diponegoro, Semarang: Badan Penerbit Universitas Diponegoro; 2007.

[7] Hakim R, Utomo. Komponen Perancangan Arsitektur Lansekap. Jakarta: PT Bumi Aksara; 2008.

[8] Dwiyanto. Kuantitas dan Kualitas Ruang Terbuka Hijau di Lingkungan Perkotaan. J Nas Arsit 2009.

[9] Madanipour. Design of Urban Space; An Inquiry into a Socio-SpatialProcess. England: John Wiley \& Son Ltd; 1996. 
[10] Kurokawa K. The Philosophy of Symbiosis (2nd Edition). New York Dan London: Academy Editions dan Distributed to the trade in the U.S.A. by St. Martin's Press; 1994.

[11] Marcus CC. Shared Outdoor Space and Community Life. Places J 2003;15:32-40.

[12] Titisari EY. Meaning of Alley as Communal Space in Kampung Kidul Dalem Malang. J Basic Appl Sci Reasearch 2012.

[13] Funo S. Dominant Issues of Three Typical Kampungs in Surabaya and Consideration on Kampung Housing System, Studies of Transitional Process of Kampungs and Evaluation of KIP. Symp. Proceeding Peran Perbaikan Kampung Dalam Pembang. Kota di Indones., Surabaya: 1985.

[14] Sihombing A. Conflicts in Public Open Spaces The Ambiguous Images of Kampungs and Kota: Conflict or Difference? Pros. Int. Semin. Manag. Confl. Public Spaces Through Urban Des., Yogyakarta: Program Magister Perancangan Kota Universitas Gajah Mada; 2004.

[15] Altman I, Zube EH. Public Places and Spaces. New York Dan London: Plenum Press; 1989.

[16] Mandeli KN. Promoting public space governance in Jeddah, Saudi Arabia. Cities 2010;27:443-55. https://doi.org/10.1016/j.cities.2010.03.001.

[17] Kropf KS. Conception of Change in the Built Environment. Urban Morphol 2001;5:2942.

[18] Raj M, Mitra B. Households, Housing and Home - Based Economic Activities in Low Income Settlements. Hous. Third World Urban Dev., London: Aspect Publishing; 1990, p. 171-82.

[19] Kellett P, Tipple AG. The Home As Workplace: A Study Of Income- Generating Activities Within The Domestic Setting. Environ Urban 2000;12:203-14. https://doi.org/10.1177/095624780001200115.

[20] Sugiyono. Metode Penelitian Kombinasi (Mix Methods). Bandung: Alfabeta; 2015.

[21] Pemerintah Kota Surabaya. Peraturan Daerah Kota Surabaya Nomor 12 Tahun 2014 Tentang Rencana Tata Ruang Wilayah Kota Surabaya Tahun 2014-2034 2014.

[22] Pemerintah Kota Mataram. Peraturan Daerah Kota Mataram Nomor 5 Tahun 2019 tentang Perubahan Atas Peraturan Daerah Nomor 12 Tahun 2011 Tentang Rencana Tata Ruang Wilayah Kota Mataram Tahun 2011 - 20312019.

[23] Mastutie F, Supardjo S, Prijadi R. Model Ruang Publik pada Permukiman Padat Kota di Kawasan Pesisir. Pros. Temu IIm. IPLBI, 2016, p. C065-72. 